\section{Adult human buccal epithelial stem cells: identification, ex-vivo expansion, and transplantation for corneal surface reconstruction}

CG Priya ${ }^{1,3}$, P Arpitha ${ }^{1,3}$, S Vaishali', NV Prajna ${ }^{2}$, K Usha ${ }^{2}$, K Sheetal ${ }^{2}$ and V Muthukkaruppan ${ }^{1}$

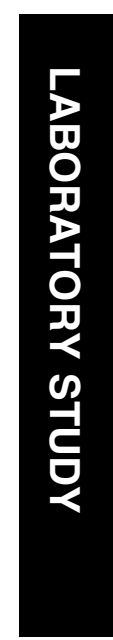

strategy for corneal surface reconstruction in bilateral LSCD. However, further studies are required to optimize the culture conditions and to look for other sources of adult SCs for better visual outcome.

Eye (2011) 25, 1641-1649; doi:10.1038/eye.2011.230; published online 23 September 2011

Keywords: buccal epithelial stem cell marker; p63 and N/C ratio; limbal stem cell deficiency

Methods The epithelial cells were isolated amnion in culture inserts with 3T3 feeder layer. The SCs were identified on the basis of two-parameter analysis using confocal microscopy, surface markers, and colonyforming efficiency (CFE). The cultured epithelium was transplanted in 10 LSCD patients followed by penetrating keratoplasty in 4 patients. The clinical outcome was followed up to 3 years.

Results A distinct population $(3.0 \pm 1.7 \%)$ of small cells expressing high levels of p63 with greater $\mathrm{N} / \mathrm{C}$ ratio was observed in buccal epithelium. The N/C ratio was found to be more appropriate than cell diameter for two-parameter analysis. These cells located in the basal layer were negative for connexin- 43 and positive for melanoma-associated chondroitin sulfate proteoglycan, containing holoclones with $0.2 \% \mathrm{CFE}$, thus representing the SC population. After transplantation of cultured epithelium with increased (sixfold) SC content, anatomical and visual improvement was observed at 13-34 months in 3/10 LSCD patients.

Conclusions The two-parameter SC marker is useful to identify and quantify buccal epithelial SCs. The transplantation of bioengineered SC-rich buccal epithelium is a

\section{Introduction}

The stem cells (SCs) for the corneal epithelium reside in the basal layer of limbus. When these SCs are severely damaged by inflammation or trauma, conjunctival epithelium invades the corneal surface where epithelial defects persist, resulting in limbal stem cell deficiency (LSCD). ${ }^{1,2}$ Novel surgical modalities have been developed over the past 25 years for reconstructing the ocular surface in such patients. Unilateral LSCD can be treated by transplantation of autologous limbal graft ${ }^{3}$ or ex-vivo expanded autologous limbal epithelium. ${ }^{4}$ However, in bilateral LSCD, limbal allograft transplantation can be performed but it requires long-term immunosuppression. ${ }^{5}$ Therefore, sources of autologous epithelium that can functionally replace the corneal epithelium have been considered as a better alternative to allogeneic transplants.

Kinoshita and Nakamura ${ }^{6}$ proposed the use of ex-vivo expanded autologous oral mucosal epithelium. Following this, transplantation of cultivated autologous oral mucosal epithelial sheet was found to be effective for
${ }^{1}$ Department of Immunology and Cell Biology, Aravind Medical Research Foundation, Dr G Venkataswamy Eye Research Institute, Madurai, Tamil Nadu, India

${ }^{2}$ Aravind Eye Hospital, Madurai, Tamil Nadu, India

Correspondence: $\checkmark$ Muthukkaruppan, Department of Immunology and Cell Biology, Aravind Medical Research

Foundation,

Dr G Venkataswamy Eye Research Institute, No. 1, Anna Nagar, Madurai 625 020, Tamil Nadu, India Tel: + 91452 4356550; Fax: + 914522530984 E-mail: muthu@aravind.org ${ }^{3}$ These authors contributed equally to this work.

Received: 3 February 2011 Accepted in revised form: 27 July 2011

Published online: 23 September 2011 
reconstructing the corneal surface in patients with total SC deficiencies. ${ }^{7-9}$ But the SC content in cultured buccal mucosal epithelium has not been analyzed, except for the reports on the expression of the putative SC markers like $\mathrm{p} 63, \mathrm{ABCG} 2, \mathrm{p} 75$, and $\beta 1$ integrin that are not exclusive to SCs. ${ }^{10,11}$ Other markers - $\alpha 6$ integrin and melanomaassociated chondroitin sulfate proteoglycan (MCSP) - were found to be restricted to clusters of cells in the mucosal papillay tips. ${ }^{12}$ Previously, we have demonstrated that the two parameters - high expression of nuclear protein p63 and a greater nucleus/cytoplasmic $(\mathrm{N} / \mathrm{C})$ ratio in combination - identified a subset of limbal epithelial cells with SC phenotype. These cells were negative for differentiation markers (K3, Cx-43, 143-3 $\sigma$ ) and proliferation marker Ki67. ${ }^{13}$ We confirmed that the combined expression of high p63 and a high N/C ratio is a distinct marker for limbal SCs on the basis of high expression of $\Delta \mathrm{N}$ p $63 \alpha$, higher-colony forming efficiency (CFE) with the ability to form holoclones, and slow cycling property. ${ }^{14,15}$ This approach of identification of SCs was confirmed by Di Iorio et al, ${ }^{16}$ on the basis of high level of p63 in combination with cell size/diameter, and by Shortt et $a l_{,}^{17}$ on the basis of the presence of cells strongly positive for $\mathrm{p} 63$ and high $\mathrm{N} / \mathrm{C}$ ratio in the limbal crypt. Hence, the objectives of this study were to characterize the native and cultured buccal mucosal epithelial cells (BMECs) for the presence of SC population based on the expression of $\mathrm{p} 63$ and $\mathrm{N} / \mathrm{C}$ ratio and to evaluate the clinical efficacy of such cultured epithelium in corneal surface reconstruction in bilateral LSCD patients.

\section{Materials and methods}

Dulbecco's modified Eagle's medium (DMEM), propidium iodide (PI), bovine serum albumin, mouse immunoglobulin (Ig)G1, mouse IgG2a, mitomycin C (MMC), Nutrient mixture F-12 (Ham's), human recombinant epidermal growth factor, insulin, penicillinstreptomycin, urea, EDTA, and Coomassie brilliant blue R250 were purchased from Sigma-Aldrich (St Louis, MO, USA); dimethyl sulfoxide and amphotericin B were from Invitrogen-GIBCO BRL (Grand Island, NY, USA); fetal bovine serum was from HyClone (Logan, UT, USA), trypsin was from Amresco (Solon, OH, USA); Dispase II was from Roche Diagnostics (Indianapolis, IN, USA); mouse anti-connexin 43 (IgG1) and streptavidinfluorescein isothiocyanate (FITC) were from BD Biosciences (San Diego, CA, USA); biotinylated goat antimouse Igs, DAKO fluorescent mounting medium containing an anti-fading agent and $15 \mathrm{mM}$ sodium azide (S3023), and endogenous biotin blocking system were from DAKO (Glostrup, Denmark); mouse monoclonal antibodies against p63 protein (clone 4A4, IgG2a) and
K12 (N-16: IgG2a) were from Santa Cruz Biotechnology, Inc. (Santa Cruz, CA, USA); streptavidin-Alexa Fluor 633 was from Molecular Probes (Eugene, OR, USA); mouse anti-cytokeratin 3 (K3) was from ImmuQuest Ltd (Cleveland, UK); cover glass $(22 \times 22 \mathrm{~mm} \mathrm{Nr}$.1) was from Menzel-Glaser (Braunschweig, Germany); and plasticware was from Nunc (Roskilde, Denmark). Monoclonal antibody to the core protein of MCSP was a generous gift of Dr Ahmed Waseem (London, UK). Airoptics extended wear bandage contact lens was purchased from Cibavision (Southampton, UK).

\section{Human samples}

The study samples included buccal mucosal biopsies from patients undergoing transplantation and human amniotic membrane (HAM) from HIV-negative elective cesarean patients after getting informed consent. The study was carried out with the approval of the institutional review board of Aravind Eye Care System and adhered to tenets of the Declaration of Helsinki.

\section{Preparation of HAM}

From the placenta, the HAM was processed and stored as described earlier. ${ }^{17}$ Before use, the HAM was de-epithelialized using $5 \mathrm{M}$ urea at $37^{\circ} \mathrm{C}$ for $5 \mathrm{~min}$ followed by mechanical scraping (JS Mehta, personal communication).

\section{Isolation of BMECs}

Buccal biopsy of $4 \times 2 \mathrm{~mm}$ was excised surgically from the interior buccal mucosal epithelium from patients (after their oral cavity was sterilized with topical povidone iodine) and washed three times with PBS containing antibiotics (50 IU $/ \mathrm{ml}$ penicillin-streptomycin and $5 \mu \mathrm{g} / \mathrm{ml}$ amphotericin B) for $10 \mathrm{~min}$ at room temperature. After removal of the submucosal connective tissues with scissors, the sample was cut into $2 \mathrm{~mm} \times 2 \mathrm{~mm}$ pieces and treated with dispase II $(2 \mathrm{mg} / \mathrm{ml})$ at $37^{\circ} \mathrm{C}$ for $45 \mathrm{~min}$. The epithelial sheet was then separated by gentle scraping and the enzyme activity was stopped by washing with DMEM containing $10 \%$ FBS. The epithelial sheet was then treated with trypsin-EDTA ( $0.05 \%$ solution) for $45 \mathrm{~min}$ to form singlecell suspension. The reaction was stopped with serum containing medium, centrifuged for $10 \mathrm{~min}$ at 1200 r.p.m., and the resultant cell pellet was resuspended in culture medium. The viability of the isolated cells was determined by Trypan blue dye exclusion method (number of cells negative for Trypan blue/total number of cells counted $\times 100$ ) . 


\section{Cultivation of BMECs}

The isolated BMECs were co-cultured on denuded HAM with MMC-inactivated 3T3 fibroblasts. ${ }^{18}$ Briefly, confluent 3T3 fibroblasts were incubated with $12 \mu \mathrm{g} / \mathrm{ml}$ $\mathrm{MMC}$ for $4 \mathrm{~h}$ at $37^{\circ} \mathrm{C}$ under $5 \% \mathrm{CO}_{2}$ to inactivate their proliferation. They were rinsed with PBS to remove MMC, trypsinized, and plated onto six-well culture plates at a density of $2 \times 10^{5}$ cells / well. Denuded HAM was spread, epithelial basement side-up, on the bottom of culture insert that was placed in the culture plate containing 3T3 fibroblasts. The isolated BMECs $\left(1-2 \times 10^{5}\right)$ were then seeded onto the denuded HAM, cultured in medium comprising DMEM and Ham's F12 $(1: 1)$ with $10 \%$ autologous serum, insulin $(5 \mu \mathrm{g} / \mathrm{ml})$, human recombinant epidermal growth factor $(5 \mathrm{ng} / \mathrm{ml})$, and penicillin-streptomycin $(50 \mathrm{IU} / \mathrm{ml})$ for 18-21 days to obtain a complete epithelial sheet. The medium was changed once in 2 days.

\section{Colony-forming assay}

To estimate the growth capacity of both native and cultured BMECs, $2.5 \times 10^{4}$ cells were cultured for 9-12 days in $35 \mathrm{~mm}$ dish on MMC-treated 3T3 fibroblasts. ${ }^{19,20}$ After removing $3 \mathrm{~T} 3$ cells by treating with $0.01 \%$ EDTA for $90 \mathrm{~s}$ at $37^{\circ} \mathrm{C}^{21}$ the epithelial colonies were stained with Coomassie brilliant blue R250. ${ }^{22}$ The CFE was calculated as number of colonies generated in each epithelial fraction/total number of cells seeded $\times 100$. The colonies were also evaluated based on the morphology of cells within the colony. ${ }^{20,23}$

\section{Immunostaining}

The native and cultured BMECs $\left(2.5 \times 10^{4}\right.$ viable cells $)$ were deposited on glass slides by centrifugation at 400 r.p.m. for 3 min using a cytospin system (Thermo Shandon, Pittsburgh, PA, USA). The cytospin smears were air dried, fixed in cold $4 \%$ paraformaldehyde for $15 \mathrm{~min}$, and washed in PBS for $2 \times 10 \mathrm{~min}^{13}$ They were then subjected to immunostaining for the following markers: cytokeratin K12, connexin-43 (Cx-43), p63, and MCSP. After treating with avidin-biotin blocking solution, the cytospin smears were stained with primary antibody and, after overnight incubation at $25^{\circ} \mathrm{C}$, biotinylated secondary antibody in a 1:200 dilution in $5 \%$ BSA was applied. Visualization was carried out with streptavidin--FITC $(1: 1000)$. Between steps, slides were washed twice in PBS and finally mounted in fluorescence mounting medium. Similarly, cryosections of buccal tissue were also immunostained for p63, K3, and K12.

In another series, after immunostaining for p63, the smears were treated with monoclonal antibody to any one of the following markers: Cx-43, K3, or MCSP. The second immunostaining was visualized with streptavidin-Alexa Fluor 633 (1: 1000). Corresponding isotype controls (mouse $\operatorname{IgG} 1, \operatorname{IgG} 2 \mathrm{a}$ ) instead of primary antibodies were applied to negative control slides. The PI (1:1000) was used as a DNA counterstain. Single immunostaining for each marker showed that there was no spatial overlap between p63 and the other antigens studied.

\section{Confocal microscopy}

Image acquisition, quantification of p63 nuclear protein, and measurement of nuclear and cellular area were carried out as described previously ${ }^{13}$ with a laserscanning microscope (Leica AOBS-TCS SP2, Heidelberg, Germany). The excitation (bandwidth) for FITC ranged from 496 to $535 \mathrm{~nm}$ using 488 argon laser; for PI from 560 to $600 \mathrm{~nm}$ using $598 \mathrm{He}-\mathrm{Ne}$ laser; and for Alexa Fluor 633 from 610 to $725 \mathrm{~nm}$ using $633 \mathrm{He}-\mathrm{Ne}$ laser. Using the above parameters, z-stack images $(1 \mu \mathrm{m})$ of 100 consecutive buccal epithelial cells were acquired for FITC/PI and transmitted light. From the z-stack images, the cellular and nuclear areas of the same 100 cells were measured using Leica confocal software (version 2.61.1537). Each cell was designated with a region of interest (ROI) number. Fluorescence intensity was quantified based on mean amplitude/pixel intensity - after reconstructing the z-stack images to a $2 \mathrm{D}$ average projection along a fixed axis. In this manner, each cell with a ROI number was identified for its nuclear and cellular area/diameter as well as for its mean amplitude for p63 expression.

\section{Two-parameter analysis}

The N/C ratio and cell diameter were obtained using Microsoft Excel. Two-parameter analysis was carried out as described by Arpitha et al, ${ }^{13}$ and presented as a scatter plot that was separated into four quadrants at 185 (mean amplitude, $y$ axis) and 0.7 (N/C ratio, $x$ axis). Statistical analysis was performed using nonparametric test for two independent samples using Mann-Whitney test. The suitability of using either cell diameter or N/C ratio as one of the parameters was also examined.

\section{Buccal mucosal epithelial cell transplantation (BMECT)}

After a 360-degree conjunctival peritomy, conjunctivalized tissue on the corneal surface and thick fibrotic subconjunctival tissues were removed. The subconjunctival spaces were treated with MMC $0.04 \%$ for $5 \mathrm{~min}$ and then vigorously washed with saline. Then, the HAM with the ex-vivo expanded buccal mucosal 
epithelial SCs (BMESCs) was placed with the buccal epithelium side facing the patient's cornea and then sutured with 10-0 nylon. The ocular surface was protected at the end of surgery with a bandage contact lens. The patient was put on topical steroids (a combination of dexamethasone with ciprofloxacin) that were tapered over a 6-month period. They were also put on tapering doses of oral prednisolone $(1 \mathrm{mg} / \mathrm{kg}$ body weight) over a 3-week period. No further or additional immunosuppression was done.

Postoperatively, the patients were followed up at $1,3,6$, and 12 months, and subsequently at 6-month interval for anatomical and visual improvement. The anatomical improvement that signifies the establishment of the limbal barrier effect was defined as reestablishment of a stable, transparent corneal epithelium, resolution of conjunctivalization, and regression of corneal vascularization. The visual improvement was defined as an increase in the visual acuity (VA) of at least two lines in Snellen chart. For patients with VA $<6 / 60$, visual improvement was defined as an increase of $2 \mathrm{~m}$ from their preoperative visual status.

\section{Results \\ Identification and characterization of stem cells
in buccal mucosal epithelium}

Immunostaining of buccal sections revealed that cells in the basal layer are strongly positive for p63 compared with cells in the superficial layers (Figures 1a and b). The viability of isolated BMECs was $>98 \%$. Cell morphology was well preserved in the cytospin smears of single-cell suspension. Epithelial cells were flat and uniformly distributed so that nuclear and cytoplasmic area could be clearly delineated (Figure 1c).

Expression level of p63 in individual cells by confocal microscopy along with $\mathrm{N} / \mathrm{C}$ ratio is presented as a scatter plot in Figure 2a. The plot shows that (1) the upper right (UR) quadrant consists of small cells characterized by high p63 (mean amplitude $\geq 185$ ) and $\mathrm{N} / \mathrm{C}$ ratio $(\geq 0.7)$; (2) the cells in the upper left (UL) quadrant are comparatively larger $(\mathrm{N} / \mathrm{C}$ ratio $<0.7)$ although with high p63 expression; (3) the cells in lower right $(\mathrm{LR})$ quadrant are small $(\mathrm{N} / \mathrm{C}$ ratio $>0.7)$ expressing low p63 (<185); and (4) the lower left (LL)
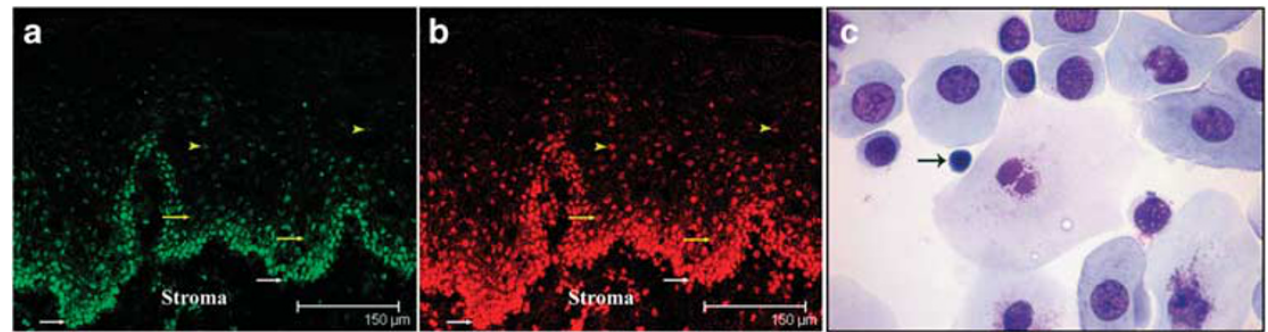

Figure 1 Confocal images of native buccal epithelium immunostained for (a) p63 (4A4 antibody) showing the presence of cells strongly positive for p63 in the basal layer (white arrows) compared with the cells in the suprabasal (yellow arrows) and superficial layers (yellow arrow heads) and (b) propidium iodide, nuclear stain. (c) Cytospin smear of single-cell suspension of BMECs stained with Giemsa showing intact cellular morphology. Both small and large cells were observed. Arrow shows a small cell with thin rim of cytoplasm.
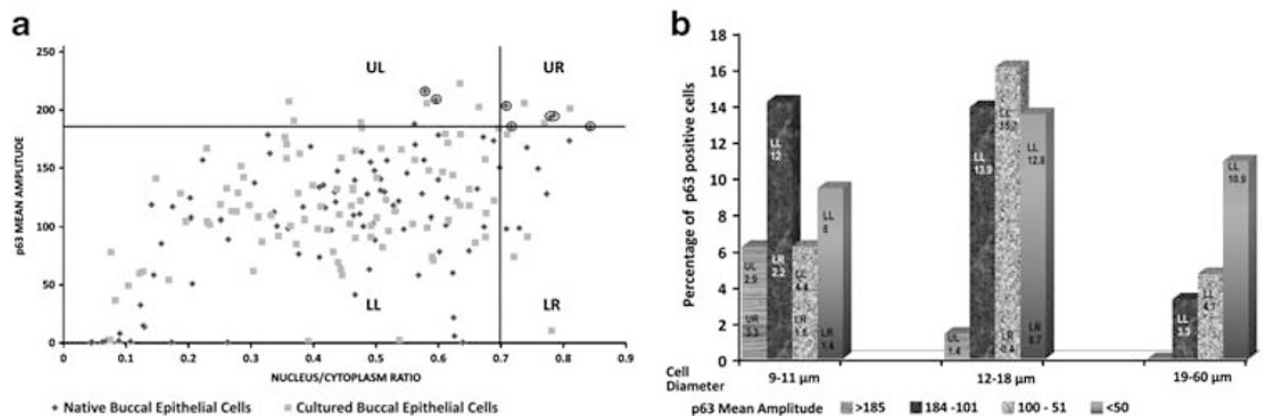

Figure 2 (a) Scatter plot for p63 expression levels and N/C ratio in native and cultured (18-21 days) buccal epithelial cells (as in Table 1). Note that a subset of small cells having N/C ratio $(>0.7)$ in the UR quadrant expressing higher levels of p63 ( $>185$ ) are present both in native and cultured epithelium. O, Highlighted native cells have diameter of 9-11 $\mu \mathrm{m}$ with high expression of p63. (b) Bar diagram of the native BMECs comparing the N/C ratio with cell diameter as one of the parameters along with p63 expression based on the data in Table 1. Note that small cells $(9-11 \mu \mathrm{m})$ with p63 >185 mean amplitude include both connexin-negative UR cells (3.3\%) and connexin-positive UL cells (2.9\%). 
quadrant contains significantly larger cells, with minimal or no p63 expression (Table 1).

\section{Nature of the distinct population in the UR quadrant}

All the cells in the UR quadrant were positive for MCSP (Figures $3 \mathrm{a}-\mathrm{C}$ ), a putative buccal SC marker, and negative for differentiation markers Cx-43 (Figures 3d-f) and K3 on the basis of observation of all the sections in a $\mathrm{z}$-stack for a given cell. In contrast, the cells in the LR, UL, and LL quadrants were positive for $\mathrm{Cx}-43$.

Cell diameter was compared with N/C ratio as one of the parameters along with p63. In addition, $6.2 \%$ of small cells with 9-11 $\mu \mathrm{m}$ diameter expressing high levels of p63 were observed and they are highlighted in Figure 2a. These two groups can be distinguished on the basis of $\mathrm{N} / \mathrm{C}$ ratio in the UR $(3.3 \%)$ and UL (2.9\%) quadrants. The cells in the UR quadrant are negative for Cx-43

Table 1 Two-parameter analysis of native and cultured buccal mucosal epithelial cells

\begin{tabular}{lcccc}
\hline & UR & $U L$ & $L R$ & $L L$ \\
\hline Native BMECS & & & & \\
$\quad$ Cells $(\%)$ & $3.0 \pm 1.7$ & $3.7 \pm 1.2$ & $6.3 \pm 4.0$ & $87.0 \pm 3.5$ \\
Cell diameter $(\mu \mathrm{m})$ & $9.5 \pm 0.8^{*}$ & $11.4 \pm 1.4$ & $10.6 \pm 1.4$ & $16.2 \pm 7.7$ \\
N/C ratio & $0.78 \pm 0.1^{*}$ & $0.52 \pm 0.1$ & $0.74 \pm 0.04$ & $0.43 \pm 0.2$ \\
p63 mean amplitude & $195.9 \pm 12.5^{\dagger}$ & $197.8 \pm 11.3$ & $135.8 \pm 32$ & $97.5 \pm 49$ \\
& & & & \\
Cultured BMECs & & & $1.7 \pm 2.1$ & \\
Cells $(\%)$ & $11.8 \pm 1.0$ & $9.7 \pm 4.6$ & $14.2 \pm 3.0$ & \\
Cell diameter $(\mu \mathrm{m})$ & $0.75 \pm 0.03^{*}$ & $0.3 \pm \pm 0.7 \pm 3.1$ & $21.9 \pm 5.8$ \\
N/C ratio & $202.7 \pm 16.2^{\dagger}$ & $205.6 \pm 13.6$ & $0.74 \pm 0.03$ & $0.33 \pm 0.2$ \\
p63 mean amplitude & & $97.8 \pm 63.5$ & $116 \pm 47$ \\
\hline
\end{tabular}

Abbreviations: UR, upper right; UL, upper left; LR, lower right; LL, lower left quadrants (refer to Figure 3). Data are expressed as mean \pm SD of three assays for both native and cultured cells.

${ }^{*} P<0.005$, both diameter and N/C ratio of UR cells significantly lower than UL and LL cells.

${ }^{\dagger} P<0.005$, p63 mean amplitude of UR cells significantly higher than LR and LL cells.

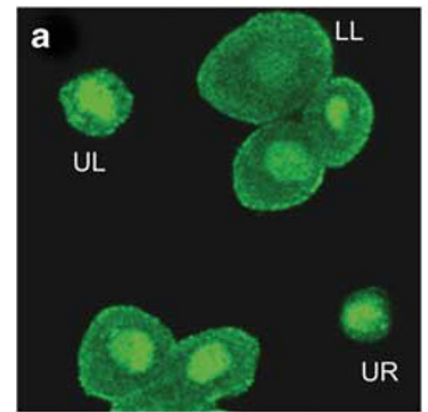

p63-green

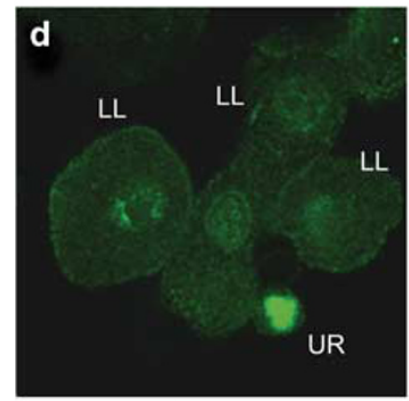

p63-green

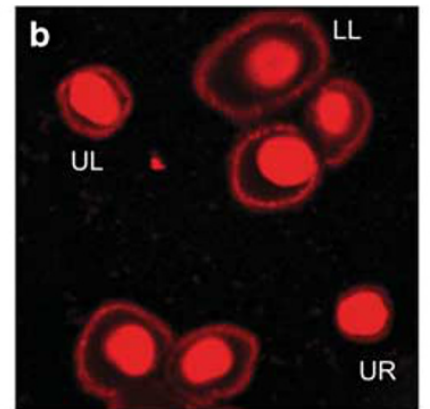

MCSP-red, Pl-red



Cx43-red, Plred

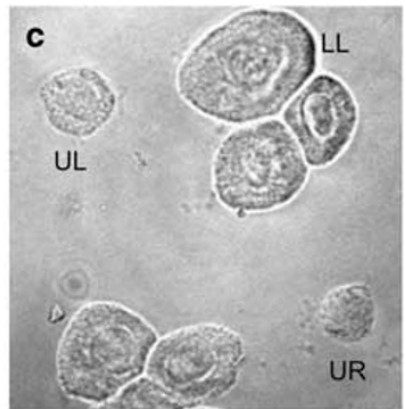

Transmitted Image

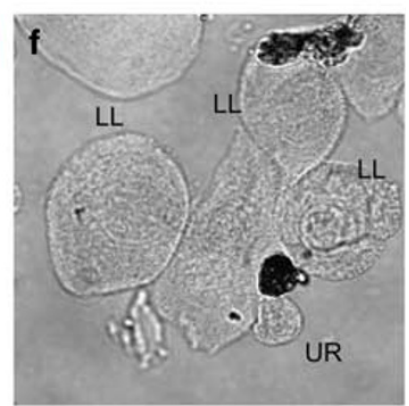

Transmitted Image

Figure 3 Characteristics of buccal epithelial cells in the UR, UL, and LL quadrants. Double immunostaining for p63 (a, d) and MCSP (b)/Cx-43 (e) revealed that UR cells are positive for MCSP and negative for Cx-43. (c, f) The transmitted image for (a, d), respectively. (a, b) UL cell: p63 mean amplitude, N/C ratio: 240, 0.47; UR cell: 223, 0.73; LL cell: 99, 0.22 and (d, e) UR cell: 192, 0.84; LL cells: 41, 0.18; $46,0.15 ; 52,0.17$, respectively. 

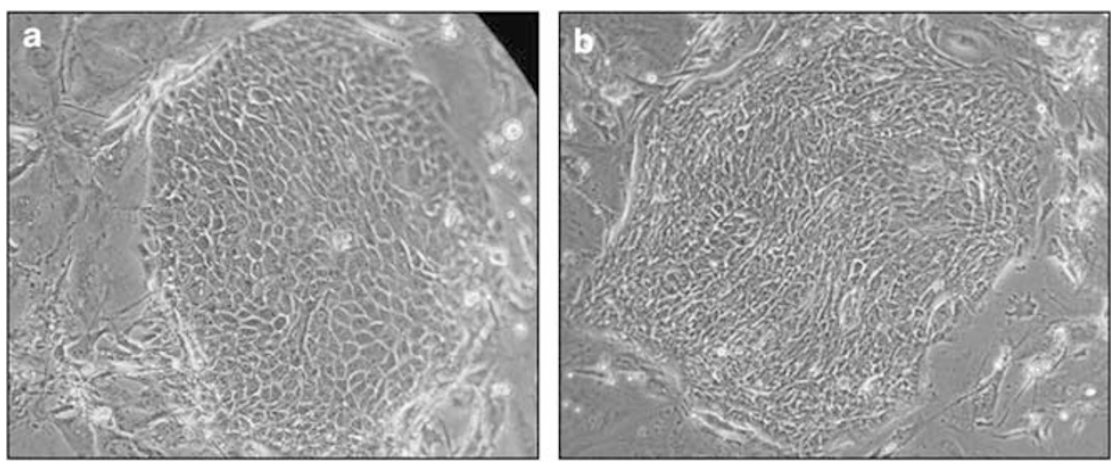

Figure 4 Phase image of a holoclone from native (a) and cultured (b) BMECs. Colony-forming assay using native and cultured BMECs revealed that both have the same CFE and ability to form holoclones.

Table 2 Ex-vivo expansion of BMESCs

\begin{tabular}{lcc}
\hline & BMECs seeded & Cultured BMECs \\
\hline Total no. of cells $\left(\times 10^{4}\right)$ & $15 \pm 5$ & $104 \pm 74$ \\
Percentage of SCs & $3.0 \pm 1.7$ & $2.0 \pm 1.0$ \\
Total no. of SCs & $4666 \pm 3055$ & $27766 \pm 23053$ \\
\hline
\end{tabular}

Data are expressed as mean $\pm \mathrm{SD}$ of three assays from three donors for both native and cultured cells. A sixfold increase in total number of stem cells was observed in cultured epithelium.

(Figure 3e) and those in the UL quadrant are positive for $\mathrm{Cx}-43$, a differentiation marker (Figure 2b). Therefore, $\mathrm{N} / \mathrm{C}$ ratio is more appropriate than cell diameter along with high p63 expression for characterization of SCs.

\section{Ex-vivo expansion of BMECs}

The buccal epithelial cells began to form colonies on denuded HAM within 3 days and a confluent epithelium was established covering the whole HAM after 12 days. At 3 weeks, the cultured BMECs showed 2 to 3 layers of stratification. The CFE of both native and cultured BMECs were $0.22 \pm 0.02$ and $0.199 \pm 0.04 \%$, respectively. Both the population of cells had the ability to form holoclones (Figure 4). Similar to the native buccal cells, the cultured cells were negative for K12.

\section{Expansion of BMESCs}

After 3 weeks of culturing the BMECs, the number of epithelial cells increased to $104 \pm 74 \times 10^{4}$ from $15 \pm 5 \times 10^{4}$. Two-parameter analysis revealed that $2.0 \pm 1.0 \%$ cells are included in the UR quadrant (Figure 2a). There was no significant difference in the percentage of SCs before and after culturing. As there was an increase in the number of BMECs after culturing, the total number of SCs increased by sixfold in cultured epithelium compared with the native cells seeded (Table 2).

\section{Surgical outcome}

The study included 10 eyes of 10 patients (Table 3) who were followed up over a mean period of 18.6 months (range: 1-38 months) after BMECT. All the patients in this series were male, ranging from 8 years to 65 years (mean: 31 years). Seven patients $(70 \%)$ were bilaterally affected and only one eye was included in the study. There were specific reasons for considering BMECT in the rest of the three unilaterally affected patients. In two of these (patients 4 and 10 in Table 3), a limbal biopsy from the fellow normal eye did not show epithelial outgrowth in explant culture, whereas in one patient (patient 3), a previous ex-vivo cultured limbal stem cell transplantation had failed.

All the 10 patients had complete LSCD as evidenced by conjunctivalization of the cornea and also by the complete absence of palisades of Vogt. The etiology of LSCD was chemical injury in nine patients and Stevens-Johnson syndrome in one. All patients had sufficient ocular tear production. Eight patients (80\%) had previous surgeries that included HAM transplantation $(n=7)$, ex-vivo cultivated limbal stem cell transplant $(n=1)$, limbal allograft $(n=1)$, and cadaver limbal graft $(n=1)$.

Transplantation of ex-vivo expanded buccal mucosal epithelium was carried out in the above 10 patients. Subsequently, penetrating keratoplasty (PKP) was performed in four patients $(40 \%)$ with stable ocular surface but with opaque cornea.

Preoperative and postoperative best-corrected VA was measured and ocular surface manifestations were inspected with a slit lamp microscope. The preoperative best-corrected VA in the operated eye in patients was $\mathrm{PL}+$ in $7,1 / 60$ in 2 , and $6 / 60$ in 1 , respectively. Of the 10 patients, 5 patients showed anatomical improvement as evidenced by absence of conjunctivalization and the presence of a stable epithelial surface (Figure 5 and Table 3). The remaining five patients had 
Table 3 Clinical features of patients recruited for the study and details of the outcome of BMECTs

\begin{tabular}{|c|c|c|c|c|c|c|c|c|c|c|}
\hline $\begin{array}{l}\text { Pt. } \\
\text { no. }\end{array}$ & $\begin{array}{l}\text { Age } \\
\text { (years)/ } \\
\text { sex }\end{array}$ & Laterality & Pre-op surgeries & $\begin{array}{c}\text { Duration } \\
\text { between } \\
\text { injury and } \\
\text { BMECT } \\
\text { (months) }\end{array}$ & $\begin{array}{c}\text { Post- } \\
\text { BMECT } \\
\text { Surgeries }\end{array}$ & $\begin{array}{l}\text { Pre-op } \\
\text { VA }\end{array}$ & $\begin{array}{l}\text { Post-op best } \\
\text { VA after } \\
\text { BMECT } \\
\text { (months) }\end{array}$ & $\begin{array}{l}\text { VA at last } \\
\text { follow-up } \\
\text { (months) }\end{array}$ & $\begin{array}{l}\text { Anat. } \\
\text { Imp. }\end{array}$ & $\begin{array}{l}\text { Vis. } \\
\text { Imp. }\end{array}$ \\
\hline 1 & $65 / \mathrm{M}$ & Bilateral & $\mathrm{AMT}$ & 60 & PKP & $\mathrm{PL}+$ & $3 / 60(6)$ & $3 / 60(13)$ & Yes & Yes \\
\hline 2 & $42 / \mathrm{M}$ & Bilateral & AMT & 10 & No & $6 / 60$ & $6 / 18(3)$ & $6 / 36(34)$ & Yes & Yes \\
\hline 3 & $34 / \mathrm{M}$ & Unilateral & CLET & 18 & No & $1 / 60$ & $6 / 12(6)$ & $6 / 12(23)$ & Yes & Yes \\
\hline $4^{*}$ & 19/M & Unilateral & AMT & 10 & PKP & PL + & $4 / 60(7)$ & FCF (23) & Yes & No \\
\hline 5 & $20 / \mathrm{M}$ & Bilateral & Nil & 24 & PKP & $\mathrm{PL}+$ & $4 / 60(6)$ & $1 / 60(12)$ & Yes & No \\
\hline 6 & $45 / \mathrm{M}$ & Bilateral & AMT & 11 & No & $\mathrm{PL}+$ & PL- (3) & PL- (22) & No & No \\
\hline 7 & $32 / \mathrm{M}$ & Bilateral & $\begin{array}{l}\text { AMT, keratoepithelioplasty, } \\
\text { limbal allograft }\end{array}$ & 120 & PKP & $\mathrm{PL}+$ & $2 / 60(4)$ & $\mathrm{PL}+(8)$ & No & No \\
\hline 8 & $16 / \mathrm{M}$ & Bilateral & AMT & 17 & No & $\mathrm{HM}+$ & $\mathrm{HM}+(1)$ & $\mathrm{HM}+(1)$ & No & No \\
\hline $9^{* *}$ & $29 / \mathrm{M}$ & Bilateral & AMT, cadaver limbal graft & 11 & No & $\mathrm{PL}+$ & $1 / 60(1)$ & $\mathrm{PL}+(38)$ & No & No \\
\hline $10^{*}$ & $8 / \mathrm{M}$ & Unilateral & Nil & 48 & No & $\mathrm{PL}+$ & $\mathrm{HM}+(4)$ & $\mathrm{PL}+(12)$ & No & No \\
\hline
\end{tabular}

Abbreviations: AMT, amniotic membrane transplantation; CLET, cultured limbal epithelial transplant; VA, visual acuity; HM, hand movement; PKP, penetrating keratoplasty, PL, perception of light; FCF, finger counting close to face; Anat. Imp., anatomical improvement; Vis. Imp., visual improvement. ${ }^{*}$ No growth on cultured limbal biopsy obtained from contralateral eye.

**Diagnosed Stevens-Johnson syndrome, all others had chemical injury.

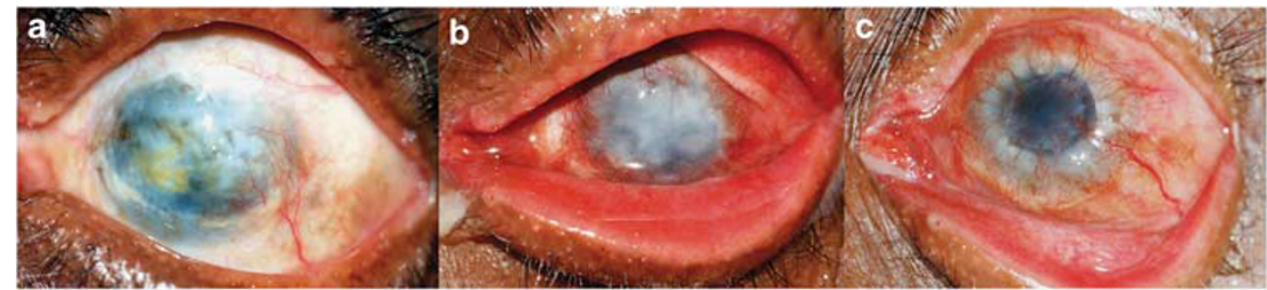

Figure 5 Anatomical and visual improvement in patient no. 1 (Table 3). Left eye of the patient showing corneal opacity, with vascularization and no distinct limbal area preoperatively (a). At 3 months after transplantation of bioengineered BMESCs, superficial vessels are limited to the periphery and limbal barrier is established (b). However, vision did not improve. View of the same eye 6 months after penetrating keratoplasty showing anatomical (c) and visual improvement from hand movement to 3/60.

reconjunctivalization and were termed as anatomical failure. Of the five patients who had anatomical improvement, three patients had visual improvement by 2 or more lines. Two patients (patients 4 and 5 in Table 3) had an initial visual improvement, but subsequently had corneal graft rejection that reduced vision.

\section{Discussion}

\section{Two-parameter stem cell marker for buccal epithelial stem cells}

One of the major factors responsible for visual improvement is the presence of SCs in the ex-vivo expanded epithelium used for transplantation. ${ }^{24}$ Investigations on this variable have not been possible to date as there is no single, specific molecular marker for epithelial SCs, especially, as the known markers are not exclusive..$^{7,9,11,25}$ The reported putative markers for BMESCs include the transcription factor p63,
ATP-binding cassette transporter (ABCG2), ${ }^{9,11}$ lowaffinity NGF receptor $\mathrm{p} 75,{ }^{25}$ and $\beta 1$ integrin. As these markers are not exclusive to SCs, it is essential to develop a specific method to identify and quantify the BMESCs.

It is now well established that high level of expression of the transcription factor p63 is a characteristic of limbal epithelial SCs (LESCs). ${ }^{13,16,17}$ The above studies have also indicated that level of expression of p63 alone was not sufficient and it was required to combine either N/C ratio ${ }^{13}$ or cell diameter ${ }^{16}$ to distinguish SCs from other cells. Thus, a small limbal basal epithelial cell with high p63 and high $\mathrm{N} / \mathrm{C}$ ratio, positive for $\Delta \mathrm{N}$ p $63 \alpha$ and $\mathrm{C} / \mathrm{EBP} \delta$ and negative for $\mathrm{Cx}-43,14-3-3 \sigma$, and $\mathrm{Ki} 67,{ }^{13,16}$ has been defined as a SC.

The above finding is now extended to buccal epithelium that shows high expression of p63 in its basal layer. Accordingly, the two-parameter analysis revealed the presence of a distinct population of small cells with large N/C ratio and expressing high levels of p63 (UR quadrant cells in Figure $2 a$ and Table 1). These UR cells 
were negative for differentiation markers $C x-43$, a gap junction protein, and $\mathrm{K} 3$, a differentiated epithelial cell marker. In contrast to the UR cells, cells observed in the other three quadrants were positive for $\mathrm{Cx}-43$ (Figure 3), indicating that they are differentiated. ${ }^{26}$ Furthermore, the UR cells were positive for MCSP, which was expressed only in groups of small cells in the tips of the papillae in buccal epithelium ${ }^{12}$ and dermal papillae. ${ }^{27}$ Although the proteoglycan shows restricted expression and is possibly involved in the maintenance of SC phenotype in epidermis, $^{28}$ this may not be an exclusive SC marker, as UL cells with low $\mathrm{N} / \mathrm{C}$ ratio were also positive (Figure 3b).

\section{Cell diameter vs N/C ratio}

The present study also compared the suitability of using either $\mathrm{N} / \mathrm{C}$ ratio or cell diameter as one of the parameters. On the basis of the analysis of the same BMEC population, we show that $\mathrm{N} / \mathrm{C}$ ratio is more appropriate than cell diameter, and thus a stringent morphological tool. In other words, two small cells expressing high levels of p63 could be distinguished by $\mathrm{N} / \mathrm{C}$ ratio, one cell with high $\mathrm{N} / \mathrm{C}$ ratio is negative for $\mathrm{Cx}-43$ and another with low $\mathrm{N} / \mathrm{C}$ ratio is positive for $\mathrm{Cx}-43$, although both were of same cell diameter (Figure 2a).

\section{Ex-vivo expansion of BMESCs in culture}

Similar to the native buccal epithelium, SCs were also identified in the cultured buccal epithelium based on two-parameter analysis. The present study confirms the earlier reports on the presence of SCs in the cultured buccal epithelium by their functional property of CFE and ability to form holoclones. ${ }^{10,29}$ Moreover, we demonstrate for the first time an increase in the total number of SCs in the ex-vivo expanded buccal epithelium, although not the percentage of SCs. These cultured BMECs were negative for the corneal epithelium-specific marker K12 and hence do not acquire the corneal phenotype, confirming the earlier reports. ${ }^{10,29}$

\section{Corneal surface reconstruction}

Our study suggests that BMECT is a useful SC therapy for severe bilateral LSCD due to chemical injury as described earlier. ${ }^{7,9,30}$ In addition, it is beneficial in some unilateral LSCD patients in whom either transplantation of autologous cultured limbal epithelium failed or was not possible (patients 3 and 4 in Table 3). Our study demonstrates that the two-step surgical procedure of BMECT followed by PKP was beneficial in one patient with significant corneal opacity. The limbal barrier effect was established in five patients (patients 1-5 in Table 3) by BMECT and visual improvement was observed in three of these patients.

The percentage of success in our study is 'suboptimal' compared with other reports that demonstrate $67-100 \%$ after buccal epithelial transplantation..$^{7-9,30,31}$ The outcome of transplantation was variable on the basis of the duration of LSCD and SC content of the epithelium. A variety of factors like the severity of the initial injury, which might permanently alter the 'limbal niche' or the inflammation, might impede the establishment of the transplanted cells, thus explaining our suboptimal results. Having established a specific method to identify buccal SCs, it is now essential to develop a correlation coefficient of clinical success with that of laboratory parameters to understand the role of associated factors responsible for a successful transplantation. In addition, it is required to optimize the culture conditions with GMP compliance to improve the SC content of the epithelium with corneal phenotype as well as to explore the possibility of using other sources of autologous adult SCs.

\section{Summary}

\section{What was known before}

- Culture method for ex-vivo expansion of human buccal mucosal epithelial cells on human amniotic membrane with autologous serum.

- Colony-forming efficiency and holoclone.

- Transplantation method.

What this study adds

- BMESCs characterized on the basis of two-parameter stem cell marker.

- A small cell located in the basal layer of buccal mucosa with high N/C ratio and high p63 expression, positive for MCSP and negative for Cx-43, identified as stem cell.

- Transplantation of cultured epithelium with increased SC content by two-parameter stem cell marker.

\section{Conflict of interest}

The authors declare no conflict of interest.

\section{Acknowledgements}

The study was supported by Defence Research and Development Organisation (DRDO), India (DLS/81/ 48222/LSRB-99/BDB/2006). We thank TIFAC-Center of Relevance and Excellence in Diabetic Retinopathy for providing confocal microscope and Mrs S Jeyalakshmi, Department of Immunology and Cell Biology, Aravind Medical Research Foundation, India, for her technical help in colony-forming assay. 


\section{References}

1 Tseng SC. Concept and application of limbal stem cells. Eye 1989; 3: 141-157.

2 Nishida K. Tissue engineering of the cornea. Cornea 2003; 22(7 Suppl): S28-S34.

3 Kenyon KR, Tseng SC. Limbal autograft transplantation for ocular surface disorders. Ophthalmology 1989; 96: 709-722.

4 Pellegrini G, Traverso CE, Franzi AT, Zingirian M, Cancedda R, De Luca M. Long-term restoration of damaged corneal surfaces with autologous cultivated corneal epithelium. Lancet 1997; 349: 990-993.

5 Tsubota K, Satake Y, Kaido M, Shinozaki N, Shimmura S, Bissen-Miyajima $\mathrm{H}$ et al. Treatment of severe ocular-surface disorders with corneal epithelial stem cell transplantation. N Engl J Med 1999; 340: 1697-1703.

6 Kinoshita S, Nakamura T. Development of cultivated mucosal epithelial sheet transplantation for ocular surface reconstruction. Artif Organs 2004; 28: 22-27.

7 Nishida K, Yamato M, Hayashida Y, Watanabe K, Yamamoto K, Adachi $\mathrm{E}$ et al. Corneal reconstruction with tissue-engineered cell sheets composed of autologous oral mucosal epithelium. N Engl J Med 2004; 351: 1187-1196.

8 Inatomi T, Nakamura T, Koizumi N, Sotozono C, Yokoi N, Kinoshita S. Midterm results on ocular surface reconstruction using cultivated autologous oral mucosal epithelial transplantation. Am J Ophthalmol 2006; 141: 267-275.

9 Chen HJ, Chen H, Lai J, Chen CC, Tsai YJ, Kuo MT et al. Persistence of transplanted oral mucosal epithelial cells in human cornea. Invest Ophthalmol Vis Sci 2009; 50: 4660-4668.

10 Hayashida Y, Nishida K, Yamato M, Watanabe K, Maeda N, Watanabe $\mathrm{H}$ et al. Ocular surface reconstruction using autologous rabbit oral mucosal epithelial sheets fabricated ex vivo on a temperature-responsive culture surface. Invest Ophthalmol Vis Sci 2005; 46: 1632-1639.

11 Ma DH, Kuo MT, Tsai YJ, Chen HC, Chen XL, Wang SF et al. Transplantation of cultivated oral mucosal epithelial cells for severe corneal burn. Eye (Lond) 2009; 23(6): 1442-1450.

12 Köse O, Lalli A, Kutulola AO, Odell EW, Waseem A. Changes in the expression of stem cell markers in oral lichen planus and hyperkeratotic lesions. J Oral Sci 2007; 49: 133-139.

13 Arpitha P, Prajna NV, Srinivasan M, Muthukkaruppan V. High expression of p63 combined with a large N/C ratio defines a subset of human limbal epithelial cells: implications on epithelial stem cells. Invest Ophthalmol Vis Sci 2005; 46(10): 3631-3636.

14 Arpitha P, Prajna NV, Srinivasan M, Muthukkaruppan V. A method to isolate human limbal basal cells enriched for a subset of epithelial cells with a large nucleus/cytoplasm ratio expressing high levels of p63. Microsc Res Tech 2008; 71(6): 469-476.

15 Arpitha P, Prajna NV, Srinivasan M, Muthukkaruppan V. A subset of human limbal epithelial cells with greater nucleus-to-cytoplasm ratio expressing high levels of p63 possesses slow-cycling property. Cornea 2008; 27(10): 1164-1170.

16 Di Iorio E, Barbaro V, Ferrari S, Ortolani C, De Luca M, Pellegrini G. Q-FIHC: quantification of fluorescence immunohistochemistry to analyse p63 isoforms and cell cycle phases in human limbal stem cells. Microsc Res Tech 2006; 69(12): 983-991.
17 Shortt AJ, Secker GA, Munro PM, Khaw PT, Tuft SJ Daniels JT. Characterization of the limbal epithelial stem cell niche: novel imaging techniques permit in vivo observation and targeted biopsy of limbal epithelial stem cells. Stem Cells (Dayton, Ohio) 2007; 25: 1402-1409.

18 Nakamura T, Endo K, Cooper LJ, Fullwood NJ, Tanifuji N, Tsuzuki $\mathrm{M}$ et al. The successful culture and autologous transplantation of rabbit oral mucosal epithelial cells on amniotic membrane. Invest Ophthalmol Vis Sci 2003; 44: $106-116$.

19 Li D, Chen Z, Song XJ, de Paiva CS, Kim HS, Pflugfelder SC. Partial enrichment of a population of human limbal epithelial cells with putative stem cell properties based on collagen type IV adhesiveness. Exp Eye Res 2005; 80: 581-590.

20 Pellegrini G, Golisamo O, Paterna P, Lambiase A, Bonini S, Rama P et al. Location and clonal analysis of stem cells and their differentiation progeny in the human ocular surface. I Cell Biol 1999; 145: 769-782.

21 Liu S, Li J, Wang C, Tan D, Beuerman R. Human limbal progenitor cell characteristics are maintained in tissue culture. Ann Acad Med Singapore 2006; 35: 80-86.

22 Budak MT, Alpdogan OS, Zhou M, Lavker RM, Akinci MA, Wolosin JM. Ocular surface epithelia contain ABCG2dependent side population cells exhibiting features associated with stem cells. J Cell Sci 2005; 118: 1715-1724.

23 Barrandon Y, Green H. Three clonal types of keratinocyte with different capacities for multiplication. Proc Natl Acad Sci USA 1987; 84: 2302-2306.

24 Rama P, Matuska S, Paganoni G, Spinelli A, De Luca M, Pellegrini G. Limbal stem-cell therapy and long-term corneal regeneration. $N$ Engl J Med 2010; 363(2): 147-155.

25 Nakamura T, Endo K, Kinoshita S. Identification of human oral keratinocyte stem/progenitor cells by neurotrophin receptor $\mathrm{p} 75$ and the role of neurotrophin/p75 signaling. Stem Cells (Dayton, Ohio) 2007; 25: 628-638.

26 Matic M, Petrov IN, Chen S, Wang C, Dimitrijevich SD, Wolosin JM. Stem cells of the corneal epithelium lack connexins and metabolite transfer capacity. Differentiation 1997; 61: 251-260.

27 Ghali L, Wong ST, Tidman N, Quinn A, Philpott MP, Leigh IM. Epidermal and hair follicle progenitor cells express melanoma-associated chondroitin sulfate proteoglycan core protein. J Invest Dermatol 2004; 122(2): 433-442.

28 Watt FM. Role of integrins in regulating epidermal adhesion, growth and differentiation. EMBO J 2002; 21(15): 3919-3926.

29 Nakamura T, Ang LP, Rigby H, Sekiyama E, Inatomi T, Sotozono $\mathrm{C}$ et al. The use of autologous serum in the development of corneal and oral epithelial equivalents in patients with Stevens-Johnson syndrome. Invest Ophthalmol Vis Sci 2006; 47: 909-916.

30 Nakamura T, Inatomi T, Sotozono C, Amemiya T, Kanamura N, Kinoshita S. Transplantation of cultivated autologous oral mucosal epithelial cells in patients with severe ocular surface disorders. Br J Ophthalmol 2004; 88: 1280-1284.

31 Inatomi T, Nakamura T, Kojyo M, Koizumi N, Sotozono C, Kinoshita S. Ocular surface reconstruction with combination of cultivated autologous oral mucosal epithelial transplantation and penetrating keratoplasty. Am J Ophthalmol 2006; 142: 757-764. 